\title{
Analisis Kelayakan Kenaikan Harga dan Biaya Produksi Usaha Tani Padi selama Pandemic Virus Covid-19 di Wilayah Kecamatan Barat Kabupaten Magetan
}

\author{
Haidar Ali \\ UIN Sunan Ampel Surabaya \\ Email: haidar.brt32@gmail.com
}

\begin{tabular}{l}
\hline Article Info \\
\hline Article history: \\
Published: Dec 25, 2020 \\
Page: $64-74$ \\
\hline
\end{tabular}

Keyword: Biaya Produksi, Kelayakan biaya, Kelayakan Usaha, dan Kebijakan

Pemerintah

\section{Abstract}

Penelitian ini bertujuan untuk menganalisis kelayakan kenaikan harga dan biaya kebutuhan produksi usaha tani padi di wilayah Kecamatan Barat Kabupaten Magetan. Hasil analisis menunjukan bahwa analisis $\mathrm{R} / \mathrm{C}$ diperoleh $1,42,>1$. Artinya biaya yang dikeluarkan sebesar Rp. 1, dapat menghasilkan penerimaan Rp. 1,42. Oleh karena itu, kelayakan pada kenaikan harga dan biaya usaha tani padi di Kecamtan Barat Kabupaten Magetan dinilai masih layak karena masih memberikan keuntungan bagi petani padi.

Kata Kunci: Biaya Produksi, Kelayakan biaya, Kelayakan Usaha, dan Kebijakan Pemerintah

This study aims to analyze the feasibility of increasing the price and production costs of rice farming in the West District of Magetan Regency. The results of the analysis show that the $R / C$ analysis is 1.42,> 1. This means that the costs incurred are Rp. 1 , can generate receipts of $R p$. 1.42. Therefore, the feasibility of increasing prices and costs of rice farming in the West District of Magetan Regency is still considered feasible because it still provides benefits for rice farmers.

Keywords: Costs Production, Cost Feasibility, Business Feasibility, and Government Policies

\section{Pendahuluan}

Indonesia merupakan negara agraris dimana sebagian besar penduduknya bekerja sebagai petani. Sektor pertanian merupakan penyumbang PDB yang relative tinggi sekitar $13,4 \%$. Sektor pertanian juga mampu

\section{Editorial Office:}

Prodi Ilmu Ekonomi Fakultas Ekonomi dan Bisnis Islam, UIN Sunan Ampel Surabaya

Jl. Ahmad Yani 117 Surabaya, Jawa Timur 60237, Indonesia.

Email: oje@uinsby.ac.id 
menyerap banyak tenaga kerja dibanding dengan sektor lain. Hampir separuh penduduk Indonesia bekerja di sektor pertanian. Sehingga sektor pertanian secara total merupakan penyumbang devisa serta pendapatan terbesar di Indonesia. Sektor pertanian masih mempunyai peluang yang besar untuk memperkuat pertumbuhan ekonomi di Indonesia dengan cara melakukan modernisasi mengikuti perkembangan zaman untuk meningkatkan hasil yang didapat. Sehingga sektor pertanian mampu mendorong munculnya kesempatan kerja yang baru lewat sektor industry (Soekartawi, 2007, p. 19).

Tabel 1. Rata-rata produktivitas terhadap hasil produksi dan luas lahan padi di Karesidenan Madiun Jawa Timur tahun 2018 (BPS, 2019)

\begin{tabular}{|c|c|c|c|c|}
\hline No & Kabupaten & $\begin{array}{c}\text { Luas } \\
\text { Lahan } \\
\text { (ha) }\end{array}$ & $\begin{array}{c}\text { Produksi } \\
\text { (ton) }\end{array}$ & $\begin{array}{c}\text { Produktivitas } \\
\text { (ton/ha) }\end{array}$ \\
\hline 1 & Pacitan & 19.987 & 93.787 & 46.92 \\
\hline 2 & Madiun & 72.604 & 452.023 & 58.54 \\
\hline 3 & Ngawi & 123.202 & 753.199 & 60.604 \\
\hline 4 & Ponorogo & 65.229 & 377.367 & 57.58 \\
\hline 5 & $\begin{array}{c}\text { Madiun } \\
\text { Kota }\end{array}$ & 1.406 & 8.662 & 61.64 \\
\hline 6 & Magetan & 49.644 & 315.400 & 63.53 \\
\hline & Jumlah & $\mathbf{3 3 3 . 0 7 2}$ & $\mathbf{2 . 0 0 0 . 4 3 8}$ & $\mathbf{3 4 8 . 8 5}$ \\
\hline
\end{tabular}

Berdasarkan tabel diatas menunjukan bahwa Kabupaten Magetan memiliki produktivitas tertinggi dalam mencapai hasil panen di Karesidenan Madiun yakni sebesar 63,53. Walaupun Kabupaten Magetan luas lahannya tidak sebesar daerah lain tetapi produktivitasnya lebih tinggi dari daerah lain yang luas lahannya lebih besar. Menurut dari data BPS dari tahun 2007-2019 produktivitas hasil panen di Kabupaten Magetan terus meningkat.
Pada awal pertengahan bulan maret tahun 2020 ini hampir seluruh dunia tengah dilanda wabah virus Covid-19. Dimana dampaknya terhadap ekonomi global dipastikan akan melambat dan menyebabkan perekonomian di Indonesia mengalami kemerosotan. Beberapa negara di dunia menerapkan peraturan lockdown sehingga mengakibatkan ekspor dan impor segala kebutuhan pokok sangat sulit diperoleh. Proses produksi dari beberapa industry terkendala kebutuhan bahan mentah yang tidak bisa masuk karena peraturan tersebut. Kementerian keuangan menyebutkan bahwa inflasi pada semester 1 tahun 2020 mengalami penurunan karena dipengaruhi oleh kebijakan PSBB sehingga berkurangnya permintaan. Inflasi pada bulan juni mencapai $1,96 \%$ yoy (year on year) (Kementerian Keuangan RI, 2020, P. 1) .

Salah satu dampak dari terjadinya inflasi adalah harga kebutuhan dan perlengkapan di sektor pertanian. Harga kebutuhan dan perlengkapan pertanian cenderung naik dan sulit diperoleh. Sedangkan satu-satunya bidang ekonomi yang tetap berjalan lancar walaupun terjadi wabah covid-19 ialah sektor pertanian. Di sektor ini pemerintah tidak dapat membatasi kerja para petani karena apabila dibatasi akan mengakibatkan hasil panen berkurang dan tidak maksimal. Apabila itu terjadi maka dampaknya ialah ketersediaan kebutuhan pangan Negara akan berkurang drastis bahkan bisa sampai tidak terpenuhi. Dengan alasan tersebut maka para petani mau tidak mau akan tetap berproduksi walaupun harga kebutuhan pokok dan perlengkapan pertanian melonjak. 
Di wilayah Kabupaten Magetan juga terkena dampak naiknya harga dan biaya kebutuhan dan perlengkapan pertanian. biaya produksi tersebut berupa biaya yang berupa (untuk upah kerja, persiapan dan penggarapan lahan, dan biaya obat-obatan serta pupuk), kemudian ada biaya yang dibayar dalam bentuk in-natura (misalnya, biaya panen, bagi hasil, sumbangansumbangan, dan pajak) (Hanafie, 2010 p. 199) Banyaknya biaya yang dikeluarkan petani akan sangat memengaruhi hasil panen. Panen padi dapat maksimal apabila seluruh kebutuhan selama masa tanam sampai panen bisa terpenuhi.

Selama pandemic covid-19 ini wilayah Kabupaten Magetan sedang berada pada masa tanam padi ketiga ini. Pada masa tanam ketiga bulan Agustus-November 2020 merupakan peralihan pada musim penghujan ke musim kemarau sehingga serangan hama yang terjadi akan lebih banyak dari musim pertama dan ketiga. Hama yang akan di hadapi misalnya (ulat, tikus, jamur, bakteri, walang, dan wereng). Sehingga kebutuhan akan obat-obatan menjadi semakin banyak dan akan menambah biaya produksi. Ditambah lagi kebutuhan tersebut akan sulit didapatkan karena terbatasnya produksi dari industry dan distribusi yang masih belum lancar karena pembatasan social (social distancing). Berdasarkan latar belakang masalah diatas, penelitian ini akan membahas mengenai permasalahan yang terjadi akibat pandemic covid-19 terhadap sektor pertanian.

1. Berapakah jumlah kenaikan harga kebutuhan pokok produksi pada usaha tani padi sebelum pandemic covid-19 dan selama pandemic covid-19?

2. Berapakah total biaya yang dikeluarkan petani dalam satu musim tanam ketiga bulan Agustus-November 2020 atau selama pandemic covid-19?

3. Bagaimana kelayakan kenaikan harga dan biaya produksi usaha tani padi di Kecamatan Barat Kabupaten Magetan selama pandemic covid-19?

4. Bagaimana kebijakan pemerintah untuk menstabilkan kenaikan biaya produksi usaha tani padi di wilayah Kecamatan Barat Kabupaten Magetan?

\section{Kajian Pustaka \\ Biaya Total (Fixed Cost)}

Total Fixed Cost (TFC), yaitu berupa biaya yang dikeluarkan oleh petani dimana besar kecilnya biaya tergantung pada besar kecilnya produksi. Berapapun jumlah yang dihasilkan biaya tetap tidak akan berubah. Misal, sewa tanah yang digarap, penyusutan alat pertanian dsb (Shinta, 2011, p. 83-84).

Biaya tetap pada usaha tani padi yang masuk dalam penelitian ini seperti ; sewa lahan, pengairan sawah dan penyusutan alat. Biaya tersebut tidak akan berubah dari awal tanam sampai dengan waktunya musim panen.

\section{Biaya Tidak Tetap (Variabel Cost)}

Total Variabel Cost (TVC), yaitu biaya dikeluarkan sesuai dengan besar kecilnya output yang dihasilkan. Misalnya, untuk bibit, obat-obatan, pengolahan lahan dan lain-lain. Semakin besar jumlah produksinya maka variable cost juga akan meningkat. Kurva biaya variable dapat dilihat pada gambar berikut (Maulidah, 2012. p. 140). 
Kurva biaya tidak tetap atau biaya variable menunjukan bahwa biaya bisa berubah sesuai dengan kondisi yang dihadapi saat produksi berlangsung. Biaya variable dapat berubah menjadi lebih besar dari batas normal ataupun bias lebih kecil dari batas normal. Kodisi yang biasanya yang mempengaruhi tersebut tidak dapat diperkirakan sebelumnya dan sulit ditebak oleh petani padi.

\section{Biaya Total (TC)}

Total Cost (TC), ialah jumlah biaya total yang dikeluarkan oleh petani didapat dari jumlah biaya tetap ditambah dengan biaya variable $\mathrm{TC}=\mathrm{FC}+\mathrm{VC}$ (Shinta, 2011, p. 83-84). Kurva biaya total menunjukan penjumlahan dari biaya variable dan biaya tetap yang dikeluarkan oleh petani padi dalam satu musim tanam. Dalam kajian pustaka ini berisi tentang referensi yang akan dijadikan acuan untuk menganalisis hasil dan pembahasan penelitian yang telah dilakukan. Termasuk ulasan mengenai teori dan konsep-konsep yang akan digunakan.

\section{Metode Penelitian}

Penelitian ini dilakukan pada petani padi dan toko pertanian Mahkota Tani sebagai penjual langsung kebutuhan dan perlengkapan pertanian kepada petani padi di wilayah Kecamatan Barat Kabupaten Magetan Jawa Timur. Waktu penelitian ini dilakukan pada bulan Oktober-November tahun 2020.

Penelitian ini menggunakan metode penelitian kualitatif dikarenakan untuk memecahkan masalah yang terjadi mengenai naiknya harga kebutuhan dan perlengkapan pertanian serta kelayakan usaha tani padi dan kebijakan pemerintah untuk menstabilkan harga. Maka dari itu untuk memahami situasi social yang terjadi diperlukannya observasi dan wawancara kepada pihak terkait yaitu, petani, pemilik toko pertanian dan pemerintah.

Pengambilan data pada penelitian ini mengutamakan penggunaan observasi dan wawancara. Menurut yang dikemukakan (sodik, 2015, p. 76-77) Observasi yang paling efektif menggunakan format yang berisi tentang kejadian atau tingkah laku yang sedang terjadi. Yang paling penting dalam obervasi ialah pengamat harus jeli dalam melakukan pengamatan sehingga hasil yang diperoleh bias dipertanggungjawabkan. Wawancara atau interview dilakukan untuk mengumpulkan data yang diperlukan dengan terjun langsung dan bertemu pihak terkait untuk melakukan percakapan yang bertujuan supaya lebih dekat dengan target yang akan dituju. Setelah melakukan wawancara maka perlu dilakukan rangkuman untuk diproses pada bagian selanjutnya. Wawancara dilakukan dalam waktu yang ditentukan untuk mengumpulkan data .

1. Data primer

Data yang didapat dari hasil wawancara langsung ke lokasi yang telah ditentukan. Hasil wawancara dengan beberapa petani padi di wilayah Kecamatan Barat Kabupaten Magetan. Data tersebut diolah sebagai hasil pengamatan peneliti.

2. Data sekunder

Data ini didapat dari observasi yang dilakukan kepada Toko Pertanian Mahkota Tani untuk mengambil daftar harga barang kebutuhan dan perlengkapan pertanian. Data tersebut 
meliputi, jurnal jual beli pada bulan

Desember 2019 dan Oktober 2020.

\section{Hasil dan Pembahasan}

\section{Analisis biaya produksi usaha tani padi}

Biaya produksi usaha tani padi merupakan seluruh komponen biaya yang dikeluarkan petani secara tunai untuk melakukan usaha taninya. Dalam struktur biaya produksi dapat dikategorikan dalam du bentuk yaitu biaya tetap (Fix Cost) dan biaya variable ( Variabel Cost). Bagi petani padi di Kecamatan Barat Kabupaten Magetan biaya tetap pada saat pandemic covid-19 tidak akan berubah karena biaya tersebut tidak dipengaruhi oleh keadaan tersebut. Sedangkan biaya variable yang mengalami perubahan karena kebutuhan pertanian dari produk industry akan mengalami kendala karena adanya pandemic covid-19 yang menyebabkan terbatasnya jumlah produksi dan sulitnya distribusi dikarenakan pembatasan social (social distancing). Jadi petani padi di Kabupaten Magetan akan mengeluarkan biaya produksi yang lebih pada biaya variable.

\section{Biaya Tetap (Fix Cost) Usaha Tani padi}

Dalam melakukan produksi petani di Kabupaten Magetan kerap sekali menggunakan peralatan untuk membantu usahanya seperti mesin sprayer dan mesin diesel sawah. Peralatan tersebut dalam tiap musim pasti mengalami penyusutan yang tetap sehingga termasuk biaya tetap yang diperhitungkan.

Sedangkan biaya pengairan dimusim tanam ketiga seharusnya bertambah dari musim sebelumnya karena musim tanam ketiga akan memasuki peralihan dari musim penghujan ke musim kemarau. Tetapi biaya tersebut tetap dan tidak berubah pada musim tanam ketiga sampai panen. Faktor faktor tersebut menjadi biaya tetap yang dimasukan pada usaha tani di wilayah Kecamatan Barat Kabupaten Magetan Jawa Timur. Hasil wawancara dengan beberapa petani, Biaya tetap dalam produksi usaha tani tersebut dapat dilihat dari table dibawah.

Tabel 2. Biaya tetap usaha tani padi dalam satu musim tanam di wilayah Kecamatan Barat Kabupaten Magetan Jawa Timur ( per Ha)

\begin{tabular}{|c|c|c|c|}
\hline No & Keterangan & $\begin{array}{c}\text { Biaya } \\
\text { sebelum } \\
\text { covid- 19, } \\
\text { Desember } \\
\text { 2019-Maret } \\
2020 \\
\end{array}$ & $\begin{array}{c}\text { Biaya selama } \\
\text { covid-19, } \\
\text { Agustus } 2020 \\
\text { - November } \\
2020\end{array}$ \\
\hline 1 & $\begin{array}{l}\text { Biaya Tetap (FC) } \\
\text { per hektar } \\
\text { Penyusutan alat } \\
>\text { sprayer (tangki } \\
\text { semprot) } \\
>\text { mesin } \\
\quad \text { diesel/sanyo }\end{array}$ & $\begin{array}{l}\text { Rp. } 10,000 \\
\text { Rp. } 20,000\end{array}$ & $\begin{array}{l}\text { Rp. } 10,000 \\
\text { Rp. } 20,000\end{array}$ \\
\hline $\begin{array}{l}2 \\
3\end{array}$ & $\begin{array}{l}\text { Pengairan } \\
\text { Sewa Lahan satu } \\
\text { musim tanam per } \\
\text { hektar }\end{array}$ & $\begin{array}{l}\text { Rp. } 900,000 \\
\text { Rp. } \\
8,000,000\end{array}$ & $\begin{array}{l}\text { Rp. } 800,000 \\
\text { Rp. } 8,000,000\end{array}$ \\
\hline & Jumlah & $\begin{array}{r}\text { Rp. } \\
8,930,000\end{array}$ & $\begin{array}{r}\text { Rp. } \\
8,830,000\end{array}$ \\
\hline
\end{tabular}

Dari hasil data penelitian tabel diatas menunjukan bahwa biaya tetap pada petani padi di wilayah Kecamatan Barat Kabupaten Magetan dalam satu hektar lahan. Biaya tetap yang dimasukan berupa sewa lahan, pengairan, dan penyusutan alat (sprayer dan diesel). Biaya penyusutan alat pada waktu sebelum covid-19 (masa tanam pertama) dan selama covid-19 ( masa tanam ketiga) relative sama tidak ada perubahan yaitu sebesar Rp. 30.000 dalam satu kali masa tanam. Untuk pengairan sebelum pandemic covid-19 petani padi menghabiskan biaya sebesar Rp. 900.000 per hektar. biaya tersebut adalah biaya pengairan sawah dengan listrik, karena sebagian besar petani 
di Kecamatan Barat mulai menggunakan sanyo dari listrik. Biaya pengairan tersebut justru turun selama pandemic covid-19 menjadi Rp. 800.000 per hektar dalam satu musim. Penurunan biaya pengaiaran disebabkan peraturan pemerintah yang memberikan subsidi untuk penggunaan listrik bagi usaha.

Biaya sewa lahan per hektar sawah di Kecamatan Barat dalam satu musim tanam sebesar Rp. 8.000.000 per hektar. Biaya sewa tidak mengalami perubahan selama pandemic covid-19. Total biaya tetap yang dikeluarkan petani padi di Kecamatan Barat selama pandemic covid-19 periode tanam musim ketiga pada bulan Agustus 2020November 2020 ialah sebesar Rp. 8.830.000. biaya tersebut mempunyai selisih Rp. $\quad 100.000$ dengan biaya sebelum pandemic covid-19 pada periode musim tanam pertama Desember 2019-Maret 2020. Selisih hanya terjadi pada pengairan yang mendapat subsidi dari pemerintah.

Biaya tidak tetap (Variabel Cost)

Faktor biaya tidak tetap pada setiap usaha berbeda-beda, pada usaha tani padi faktor yang menjadi biaya tidak tetap ialah ; benih padi, pupuk tanaman, obat-obatan pertanian, dan tenaga kerja. Selama pandemic covid-19 biaya tidak tetap mengalami perubahan yang signifikan, karena harga dari benih, pupuk, dan obatobatan pertanian yang diproduksi oleh industry menjadi langka dan sulit didapat akibat pembatasan social (social distancing).

Sedangkan biaya untuk tenaga kerja relative sama dengan musim tanam pertama sebelum adanya covid-19. Dari hasil penelitian kepada salah satu toko obat pertanian yaitu Mahkota Tani di Kecamatan
Barat Kabupaten Magetan. Toko obat pertanian Mahkota Tani menjual langsung kepada petani (R2) berbagai macam obat pertanian, benih padi, pupuk non subsidi. Data yang diambil ialah data sekunder dari harga kebutuhan produksi usaha tani yang dimiliki Toko Pertanian Mahkota Tani. Adapun hasil yang sudah didapat mengenai faktor biaya tetap pada satu kali musim tanam dan harga produknya dapat disajikan data dan diuraikan sebagai berikut ;

\section{Tabel 3. Faktor Biaya tidak tetap dalam satu musim tanam usaha tani padi di wilayah Kecamatan Barat Kabupaten Magetan Jawa Timur (per Ha)}

\begin{tabular}{|c|c|c|c|}
\hline $\begin{array}{l}\mathbf{N} \\
\mathbf{0}\end{array}$ & Keterangan & $\begin{array}{l}\text { Biaya } \\
\text { sebelum } \\
\text { covid- 19, } \\
\text { Desember } \\
2019 \text {-Maret } \\
2020 \\
\end{array}$ & $\begin{array}{l}\text { Biaya selama } \\
\text { covid-19, } \\
\text { Agustus } \\
2020- \\
\text { November } \\
2020 \\
\end{array}$ \\
\hline & $\begin{array}{l}\text { Biaya tidak tetap } \\
\text { (VC) }\end{array}$ & & \\
\hline 1 & Benih padi $\quad 30 \mathrm{~kg}$ & Rp. 360,000 & Rp. 390,000 \\
\hline 2 & $\begin{array}{l}\text { Biaya pupuk } \\
>\text { Urea 200kg } \\
>\text { ZA } 150 \mathrm{~kg} \\
>\text { SP 36/40 } 200 \mathrm{~kg} \\
>\text { Phonska } 300 \mathrm{~kg} \\
>\text { KCL } \quad 20 \mathrm{~kg}\end{array}$ & $\begin{array}{l}\text { Rp. } 360,000 \\
\text { Rp. } 210,000 \\
\text { Rp. } 400,000 \\
\text { Rp. } 690,000 \\
\text { Rp. } 180,000\end{array}$ & $\begin{array}{l}\text { Rp. } 700,000 \\
\text { Rp. } 300,000 \\
\text { Rp. } 1,080,000 \\
\text { Rp. } 1,200,000 \\
\text { Rp. } 180,000\end{array}$ \\
\hline 3 & $\begin{array}{l}\text { Obat pertanian } \\
>\text { Basmirata } 12 \text { pcs } \\
>\text { Virtaco } \quad 2 \text { botol } \\
>\text { Filia } \quad 2 \text { botol } \\
>\text { Score } \quad 1 \text { botol } \\
>\text { Fostin } 2 \text { botol } \\
>\text { Amistar } 2 \text { botol } \\
>\text { Plenum } 2 \text { pcs } \\
>\text { Obat tikus } 5 \text { pcs }\end{array}$ & $\begin{array}{l}\text { Rp. } 144,000 \\
\text { Rp. } 370,000 \\
\text { Rp. } 220,000 \\
\text { Rp. } 150,000 \\
\text { Rp. } 136,000 \\
\text { Rp. } 440,000 \\
\text { Rp. } 360,000 \\
\text { Rp. } 100.000\end{array}$ & $\begin{array}{l}\text { Rp. } 156,000 \\
\text { Rp. } 400,000 \\
\text { Rp. } 224,000 \\
\text { Rp. } 154,000 \\
\text { Rp. } 138,000 \\
\text { Rp. } 446,000 \\
\text { Rp. } 370,000 \\
\text { Rp. } 100,000\end{array}$ \\
\hline 4 & $\begin{aligned} \text { Biaya Tenaga Kerja } \\
>\text { Bajak sawah } \\
>\text { Pemopokan } \\
\text { pematang sawah } \\
\text { (3orang) } \\
>\text { penanaman } \\
>\text { sulam padi ( } 3 \\
\text { orang) } \\
>\text { tahap panen }\end{aligned}$ & $\begin{array}{l}\text { Rp. } 1,400,000 \\
\text { Rp. } 240,000\end{array}$ & $\begin{array}{l}\text { Rp. } 1,400,000 \\
\text { Rp. } 240,000 \\
\text { Rp. } 2,800,000\end{array}$ \\
\hline
\end{tabular}

Sumber : Analisa Data, 2020 
Data dari tabel dan analisis dengan grafik maka perhitungan semua faktor biaya variabel mengalami perubahan kenaikan harga yang signifikan. Sebelum pandemic covid-19 petani mengeluarkan biaya variable sebesar Rp. 10,060.000 pada musim tanam pertama sekitar bulan Desember 2019-Maret 2020. Namun selama pandemic covid-19 petani padi mengeluarkan biaya yang lebih banyak karena kebutuhan produksi yaitu benih, pupuk dan obat-obatan pertanian mengalami kenaikan harga. Kenaikan harga mencapai Rp. 11,768.000. Rata-rata kenaikan biaya tidak tetap pada satu musim selama pandemic covid-19 adalah $16 \%$.

Faktor pertama yaitu benih padi yang awalnya harga rata-rata sekitar Rp. 60.000 per $5 \mathrm{~kg}$ kini selama pandemic covid-19 mengalami kenaikan dengan harga Rp. 65.000 per $5 \mathrm{~kg}$. kenaikan harga disebabkan oleh kelangkaan produk benih berkualitas karena pembatasan social sehingga distribusi mengalami kendala. Wilayah Kecamatan Barat Kabupaten Magetan paling banyak menerima benih padi berkualitas dari daerah Jawa Tengah.

Faktor kedua adalah biaya pupuk yang mengalami kenaikan yang sangat tinggi yakni $88 \%$ atau Rp. 1.620.000 menjadi Rp. 3.460.000. Yang awalnya di musim petama bulan Desember 2019-Maret 2020 sebelum pandemic petani mengeluarkan biaya pupuk sebesar Rp. 1.840.000. kenaikan biaya pupuk yang sangat tinggi dikarenakan kuota pupuk subsidi dari pemerintah dikurangi pada awal tahun 2020 dan terus berkurang selama pandemic covid-19. Petani padi di Kabupaten Magetan termasuk yang terkena dampak pengurangan pupuk subsidi. Tetapi mau tidak mau petani padi harus tetap berproduksi selama kondisi seperti ini karena hanya usaha pertanian yang tetap bertahan untuk menjaga ketahanan pangan nasional. Oleh karena itu petani padi di Kabupaten Magetan diminta untuk beralih atau menambah kekurangan pupuk subsidi dengan pupuk non subsidi. Walaupun pupuk non subsidi mempunyai harga yang mahal dibanding pupuk subsidi tetapi kualitas pupuk non subsidi jauh diatas pupuk subsidi. Dengan kualitas pupuk non subsidi yang jauh lebih bagus diharapkan hasil panen padi juga mengalami peningkatan sehingga biaya pupuk yang lebih besar bisa ditutupi dengan hasil panen yang leih banyak. Oleh karena itu pemerintah meminta industri untuk memperbanyak produksi pupuk non subsidi dan memperlancar distribusi ke daerah.

Faktor ketiga yang terkena dampak selama pandemic covid-19 dan mempengaruhi biaya tidak tetap yaitu harga semua obat-obatan pertanian juga mengalami kenaikan. Kenaikan harga obatobatan pertanian tidak terlalu besar rata-rata hanya berkisar Rp. 5.000 per pc. Sama seperti benih padi, kenaikan harga obatobatan pertanian diakibatkan oleh kelangkaan barang yang sulit didapat karena distribusi barang yang dibatasi akibat pembatasan social. Industri obat-obatan pertanian juga mengalami penurunan produksi karena jumlah karyawan yang bekerja juga dibatasi.

Di Kabupaten Magetan rata-rata petani menggunakan obat-obatan yang kualitasnya baik. Pada musim sebelumnya yaitu musim tanam pertama petani menghabiskan sekitar Rp. 1.910.000 dalam satu musim untuk pembelian obat-obatan pertanian. pada 
musim tanam kedua selama panemic covid19 biaya naik menjadi Rp. 1.988.000. kenaikan biaya obat-obatan pertanian selama satu musim pada pandemic covid-19 sebesar Rp. 78.000. Sedangkan biaya tenaga kerja tidak mengalami perubahan selama pandemic covid-19.

\section{Biaya Total (Fix Cost)}

Penjumlahan biaya total petani padi di di Kecamatan Barat Kabupaten Magetan dapat diihat dapat pada tabel berikut ini;

Tabel 5. Biaya total dalam satu musim tanam usaha tani padi di wilayah Kecamatan Barat Kabupaten Magetan Jawa Timur (per Ha)

\begin{tabular}{|c|c|c|c|}
\hline No & Keterangan & $\begin{array}{l}\text { Biaya } \\
\text { sebelum } \\
\text { covid- 19, } \\
\text { Desember } \\
\text { 2019-Maret } \\
2020\end{array}$ & $\begin{array}{l}\text { Biaya selam } \\
\text { covid-19, } \\
\text { Agustus } \\
2020- \\
\text { November } \\
2020 \\
\end{array}$ \\
\hline 1 & $\begin{array}{l}\text { Biaya Tetap (FC) } \\
\text { Sewa Lahan } \\
\text { Penyusutan Alat } \\
\text { Pengairan sawah }\end{array}$ & $\begin{array}{l}\text { Rp. } 8,000,000 \\
\text { Rp. } 30.000 \\
\text { Rp. } 900,000\end{array}$ & $\begin{array}{l}\text { Rp. } 8,000,000 \\
\text { Rp. } 30,000 \\
\text { Rp. } 800,000\end{array}$ \\
\hline 2 & $\begin{array}{l}\text { Biaya variable } \\
\text { (VC) } \\
\text { Benih padi } \\
\text { Pupuk } \\
\text { Obat-obatan } \\
\text { Biaya Tenaga Kerja }\end{array}$ & $\begin{array}{l}\text { Rp. } 360,000 \\
\text { Rp. } 1,840,000 \\
\text { Rp. } 1,910,000 \\
\text { Rp. } 5,940,000\end{array}$ & $\begin{array}{l}\text { Rp. } 390,000 \\
\text { Rp. } 3,460,000 \\
\text { Rp. } 1,988,000 \\
\text { Rp. } 5,940,000\end{array}$ \\
\hline & Total Cost (TC) & Rp.18,980,000 & Rp.20,608,000 \\
\hline
\end{tabular}

Sumber : Analisa Data, 2020

Data dari tabel dan analisis dengan grafik penjumlahan biaya tetap dan biaya variable diatas diperoleh total biaya dalam satu musim tanam padi di Kecamatan Barat sebesar Rp. 20.608.000. biaya tersebut dikeluarkan pada musim tanam ketiga bulan Agustus 2020-November 2020 selama pandemic covid-19. Sedangkan biaya yang dikeluarkan petani padi sebelum pandemic covid-19 pada musim tanam pertama bulan Desember 2019-Maret 2020 sebesar Rp. 18.980.000. Selisih yang dihasilkan sebesar Rp. 1.628.000 atau sekitar 8,5\%.
Analisis Kelayakan Kenaikan Harga dan Biaya Usaha Tani Padi Selama Pandemic Covid-19 Di Kecamatan Barat

$$
\begin{aligned}
& \mathrm{TR}=\text { Total Penerimaan } \\
& \mathrm{TC}=\text { Total Biaya Usaha Tani }
\end{aligned}
$$

\section{Analisa Break Even Point (BEP)} digunakan untuk mengetahui batas nilai produksi dan harga suatu usaha menemui titik impas, yaitu suatu usaha tidak mengalami kerugian maupun keuntungan usaha dapat dikatakan layak apabila jumlah output lebih besar daripada jumlah BEP produksi. Sedangkan BEP harga harus lebih rendah dari harga yang berlaku sekarang. Untuk menganalisa BEP pada kelayakan kenaikan harga produksi usaha tani padi maka dapat dilihat pada rumus berikut ini (Dodi Normansyah, 2014 );

BEP Produksi $=\frac{\text { Total Biaya }}{\text { Harga Jual }}=\frac{20.608 .000}{4.600 .000}=$ 4,48 Ton

BEP Harga $=\frac{\text { Total Biaya }}{\text { Total Produksi }}=\frac{20.608 .000}{6,4}=$ Rp. 3.220 .000

Tabel 5 : Analisis BEP

\begin{tabular}{llc}
\hline No & \multicolumn{1}{c}{ Keterangan } & Jumlah \\
\hline $\mathbf{1}$ & Biaya Total (per Ha) & Rp. 20.608.000 \\
$\mathbf{2}$ & Jumlah Produksi (per Ha) & 6,4 Ton \\
$\mathbf{3}$ & Harga Jual (Per Ton) & Rp. 4.600.000 \\
$\mathbf{4}$ & BEP Produksi (per Ha) & 4,48 Ton \\
$\mathbf{5}$ & BEP Harga (Per Ton) & Rp. 3.220.000 \\
\hline
\end{tabular}

Hasil analisis menggunakan grafik BEP diperoleh bahwa untuk memperoleh laba maka produksi usaha tani padi di Kecamatan Barat Kabupaten Magetan minimal sebesar 4,48 Ton (Per Ha). Sedangkan penentuan harga jual oleh petani agar tidak mengalami kerugian atas biaya produksi maka harga jualnya minimal sebesar Rp. 3.220.000 (per Ton). Sedangkan untuk mendapat keuntungan, hasil produksi dan harga jual harus diatas kurva BEP. Maka dari itu kelayakan pada kenaikan harga dan biaya 
usaha tani padi di Kecamatan Barat Kabupaten Magetan dinilai masih layak karena masih memberikan keuntungan bagi petani padi. Dimana petani padi mampu menghasilkan panen rata-rata sebesar 6,4 Ton (per Ha) selama pandemic covid-19. Sedangkan harga penjualan hasi produksi usata tani padi selama pandemic covid-19 mampu mencapai harga Rp. 4.600 .000 (per Ton).

Suatu usaha dikatakan layak jika efisiensi pada penggunaan biaya dan total perbandingan biaya total yang dikeluarkan oleh petani padi dengan total penerimaan yang dihasilkan. Usaha tani padi merupakan usaha yang dijalankan setiap musim, maka kelayakan usaha tani padi dapat dilihat dari besarnya R/C Ratio (Saeri, 2018. p. 99) . Hasil analisis kelayakan usaha tani padi selama pandemic covid-19 di Kecamatan Barat Kabupaten Magetan dapat dilihat pada rumus berikut ;

$\mathrm{R} / \mathrm{C}=\frac{T R}{T C}$

$\mathrm{R} / \mathrm{C}=\frac{29.440 .000}{\mathbf{2 0 , 6 0 8 , 0 0 0}}=1,42$

Keterangan : $\mathrm{R}=$ Ratio

$\mathrm{C}=$ Cost

$\mathrm{TR}=$ Total Revenue/ Total

Penerimaan

$$
\mathrm{TC}=\text { Total Cost } / \text { Total Biaya }
$$

Kriteria R/C Ratio antara lain :

$\mathrm{R} / \mathrm{C}$ Ratio > 1, maka usaha tani padi dikatakan layak

$\mathrm{R} / \mathrm{C}$ Ratio $=1$, maka dikatakan BEP

$\mathrm{R} / \mathrm{C}$ Ratio < 1, maka usaha tani padi dikatakan rugi

Hasil R/C Ratio usaha tani padi di

Kecamatan Barat Kabupaten Magetan menunjukan nilai 1,42 sehingga menurut kriteria masih layak diusahakan. Hasil R/C Ratio 1,42 dapat diartikan bahwa setiap biaya yang dikeluarkan Rp.1, maka dapat menghasilkan penerimaan sebesar Rp. 1,42. Oleh karena itu, walaupun harga dan biaya kebutuhan pokok usaha tani padi semakin meningkat selama pandemic covid-19 petani padi tidak mengalami kerugian. Sehingga usaha tani padi di Kecamatan Barat Kabupaten Magetan masih layak dijalankan.

Analisis Kebijakan Pemerintah Untuk Menstabilkan Naiknya Harga Kebutuhan produksi Dan Hasil panen Petani Padi Selama Pandemic Virus Covid-19 Di Wilayah Kecamatan Barat Kabupaten Magetan

Sektor pertanian merupakan satusatunya sektor ekonomi yang tetap bertahan dan terus berjalan ditengah banyaknya krisis yang dihadapi. Bahkan sektor pertanian khususnya usaha tani padi merupakan sektor yang paling Tangguh dalam membantu stabilitas ekonomi di Indonesia. Sektor pertanian menjadi pengaman untuk kebutuhan pangan bagi kurang lebih 267 juta penduduk di Indonesia. Disisi lain ditengah wabah covid-19 sektor pertanian menjadi peluang yang baik bagi petani untuk meningkatkan kesejahteraan karena produk pertanian banyak dicari oleh konsumen untuk memenuhi kebutuhan sehari-hari dikarenakan adanya aturan social distancing. Banyak masyarakat yang terdampak covid19 berperilaku panic buying, di wilayah Kabupaten Magetan sendiri tak sedikit masyarakat membeli banyak atau memborong hasil pertanian di pasar supaya memiliki stok pangan yang banyak sehingga memenuhi kebutuhan selama waktu tertentu. Dengan begitu maka stok bahan pangan dipasar menjadi terbatas sehingga harga relative naik signifikan ditengah wabah covid-19 (Kementan, 2020).

Oleh karena itu pemerintah dituntut untuk menstabilkan harga kebutuhan produksi pertanian dan harga bahan pangan di pasar. Kebijakan pemerintah diperlukan guna meningkatkan produksi padi selama pandemic covid-19. kebijakan pemerintah dalam meningkatkan hasil produksi harus disertai dengan menekan biaya produksi yang semakin melonjak. Pemerintah pusat dan pemerintah daerah Kabupaten Magetan menerapkan beberapa strategi untuk mengatasi dampak covid-19 terhadap harga 
kebutuhan produksi usaha tani agar stabil dan tidak terus melonjak supaya petani padi dapat meningkatkan produksinya guna memenuhi kebutuhan pangan masyarakat di Indonesia. Beberapa strategi tersebut yaitu (Kementan, 2020);

1. Mengamankan sarana produksi (pestisida, benih, pupuk dan alat pertanian). Kementerian pertanian berusaha untuk mengamankan produksi dan sarana pertanian untuk menjaga harga kebutuhan pertanian tidak terus melambung tinggi. Impor bahan baku produksi pestisida, benih, pupuk dan alat pertanian tetap dilakukan walaupun diberlakukan pembatasan social dari berbagai negara didunia. Agar produksi kebutuhan tersebut bisa memenuhi permintaan semua petani di Indonesia.

2. Mengamankan jalur distribusi pupuk subsidi agar berjalan lancar. Dimusim tanam ketiga (MT3) pupuk subsidi mengalami pengurangan, sehingga ditakutkan biaya produksi meningkat. Walaupun pupuk subsidi dikurangi tetapi distribusi harus berjalan lancar untuk memenuhi ketersediaan. Hal ini dilakukan untuk mengantisipasi penurunan produktivitas petani padi.

3. Memberikan jaminan pasokan hasil pertanian agar tidak ada penimbunan. Ketika perilaku sebagian masyarakat yang terdampak covid-19 memunculkan panic buying dengan berbondong-bondong membeli kebutuhan pangan, maka ditakutkan akan mengakibatkan kehabisan stok bahan pangan, sehingga harga menjadi naik. Maka pemerintah perlu menjamin ketersediaan bahan pangan dan komoditas lain tercukupi selama pandemic covid-19.
4. Menjaga kestabilan harga hasil tanaman padi supaya seimbang dengan harga beras dipasaran. Dengan harga beras yang stabil maka harga gabah juga relative terjaga tidak ada penurunan. Sehingga petani padi tetap memperoleh keuntungan walaupun harga dan biaya kebutuhan usaha padi meningkat.

\section{Kesimpulan}

Berdasarkan penelitian yang telah dilaksanakan di wilayah Kecamatan Barat Kabupaten Magetan selama Bulan Agustus 2020 - November 2020 atau selama pandemic covid-19, maka hasil penelitian diperoleh bahwa adanya perubahan harga dan biaya yang cukup signifikan selama pandemic covid-19 dengan biaya total (Total Cost) sebesar Rp. 20.608.000 selisih Rp. 1.628 .000 (per Ha). Dimana sebelum pandemic covid-19 pada MT 1 biaya yang dikeluarkan sebesar Rp. 18.980.000. Sedangkan pendapatan bersih petani selama pandemic covid-19 sebesar Rp. 29.440.000 (per Ha). Analisis BEP diperoleh bahwa produksi padi minimal harus 4,48 Ton (Per Ha). Sedangkan penentuan harga jual oleh petani minimal sebesar Rp. 3.220.000 (per Ton). Pada panen saat ini petani padi mampu menghasilkan panen rata-rata sebesar 6,4 Ton (per Ha) selama pandemic covid-19. Sedangkan harga penjualan padi selama pandemic covid-19 mampu mencapai harga Rp. 4.600.000 (per Ton). Analisis R/C diperoleh 1,42, yang berarti menurut kriteria R/C Ratio > 1. Artinya biaya yang dikeluarkan sebesar Rp. 1, dapat menghasilkan penerimaan Rp. 1,42. Oleh karena itu, kelayakan pada kenaikan harga dan biaya usaha tani padi di Kecamatan 
Barat Kabupaten Magetan dinilai masih layak karena masih memberikan keuntungan bagi petani padi. Maka usaha tani padi di Kecamatan Barat Kabupaten Magetan masih layak dijalankan meski harga dan biaya produksi meningkat.

\section{Peran pemerintah mengenai} kebijakan dalam menerapkan beberapa strategi guna menstabilkan biaya produksi dan harga hasil produksi usaha tani. Kebijakan tersebut memunculkan beberapa strategi yang dapat dilakukan seperti; Mengamankan sarana produksi (pestisida, benih, pupuk dan alat pertanian), Mengamankan jalur distribusi pupuk subsidi agar berjalan lancar, Memberikan jaminan pasokan hasil pertanian agar tidak ada penimbunan, Menjaga kestabilan harga hasil tanaman padi supaya seimbang dengan harga beras dipasaran. Kebijakan tersebut dilakukan Agar usaha tani padi khususnya di wilayah Kecamatan Barat Kabupaten Magetan menjadi semakin layak untuk meningkatkan hasil produksi. Bagi pemerintah khususnya pemerintah setempat agar memberikan sosialisasi apabila terjadi kenaikan harga dan biaya produksi usaha tani padi selama pandemic covid-19, agar petani padi tidak terkejut dengan kenaikan harga kebutuhan produksi yang cukup signifikan. Kemudian pemerintah juga harus memberikan penyuluhan kepada petani padi bahwa berkurangnya jatah pupuk subsidi tidak membuat masalah. Karena pupuk non subsidi mampu untuk mencukupi kekurangan dan kualitas pupuk non subsidi jauh diatas pupuk subsidi. Sehingga produksi usaha tani padi di Kecamatan Barat Kabupaten Magetan bisa maksimal dan produktivitasnya meningkat. Bagi petani padi karena hasil analisis kelayakan usaha tani padi masih dikatakan layak, maka petani padi harus tetap melanjutkan usaha taninya selama pandemic covid-19 dan memperbaiki sistem produksi yang masih belum maksimal. Pemerintah juga sudah menerapkan kebijakan yang tepat untuk menstabilkan biaya produksi dan harga hasil produksi. Dalam melakukan produksi petani dituntut untuk lebih mengutamakan efektivifanya supaya hasil produksi lebih produktif. Sehingga petani tidak perlu khawatir mengenai kelanjutan usaha tani padi dan kesejahteraan hidupnya..

\section{Daftar Pustaka}

Armaeni Dwi Humaerah, Dodi Normansyah, Siti Rochaeni. "Analisis Pendapatan Usaha Tani Sayuran Di Kelompok Tani Jaya, Desa Ciaruteun Ilir, Kecamatan Cibung Bulan, Kabupaten Bogor.” Jurnal Agribisnis Vol. 8, no. 1 June (2014) : 29-44. 2014 Badan Pusat Statistik. "Luas Panen, Dan Produktivitas Menurut Kecamatan."

Badan Pusat Statistk Kabupaten Magetan, Oktober 2019. https://magetankab.bps.go.id/statictable /2019/10/30/163/luas-panen-produksi dan-produktivitas-padi-menurut kecamatan-2018.html diakses pada tanggal 14 Juli 2020.

Badan Pusat Statistik, Badan Pusat Statistik. "Luas Panen Dan Produkstivitas Padi Di Provinsi Jawa Timur Menurut Kabupaten/Kota," Oktober 2019. https://jatim.bps.go.id/statictable/2019/ 10/08/1583/luas-panen-produksi-danproduktivitas-padi-di-provinsi-jawatimur-menurut-kabupaten-kota-ha- 
2018.html diakses pada tanggal 9 Juli 2020 .

Bappeda, Badan Pembangunan Daerah.

"Badan Pembangunan Daerah

Kabupaten Magetan,” 2013.

http://bappeda.jatimprov.go.id/bappeda

/wp-content/uploads/potensi-kab-kota-

2013/kab-magetan-2013.pdf diakses

pada tanggal 12 Juli 2020.

Hanafie, Rita. Pengantar Ekonomi

Pertanian. Yogyakarta: ANDI OFFSET, 2010.

Kementan, Biro Perencanaan Sekertariat Jenderal. "Dampak Covid-19 Terhadap

Sektor Pertanaian." Buletin

Perencanaan Pembangunan Pertanian volume 1 (2020): 2.

kementerian Keuangan RI."Kinerja APBN

Semester 1 Untuk Respon Pandemi

Covid-19." Siaran Pers SP-52 (2020):

1.

Moh. Saeri. Usaha Tani Dan Analisisnya.

Malang: Unidha Press, 2018.

Sandu Suyoto, Ali Sodik. Dasar Metodologi

Penelitian. Yogyakarta: Literasi Media

Publishing, 2015.

Shinta, Agustina. Ilmu Usaha Tani. Malang:

UB Press, 2011.

Silvana Maulidah. Pengantar Manajemen

Agribisnis. Malang: UB Press, 2012

Soekartawi. "E-Agribisnis: Teori Dan

Aplikasi." Seminar Nasional Aplikasi

Teknologi Informasi, June 16 (2007).

M-19

Subandriyo. 2016. Pengaruh Kebijakan

Pemerintah Terhadap Pendapatan

Petani Kakao Di Kabupaten Jayapura.

Yogyakarta: Deepublish. 